\title{
NAPLŇOVÁNÍ STŘEDNĚDOBÝCH CÍLŮ MORAVSKOSLEZSKÉHO KRAJE V NÁVAZNOSTI NA REALIZACI REGIONÁLNÍHO OPERAČNÍHO PROGRAMU NUTS II MORAVSKOSLEZSKO 2007-2013
}

\section{FULFILLMENT OF MIDDLE TERM AIMS OF MORAVIAN-SILESIAN REGION AMONGST THE CONTINUITY OF REALIZATION OF REGIONAL OPERATIONAL PROGRAM NUTS II MORA VSKOSLEZSKO 2007-2013}

\author{
ING. IVANA JANEČKOVÁ \\ Katedra regionální ekonomie a správy $\mid$ Dep. of Regional Economics and Administration \\ Ekonomicko-správni fakulta Faculty of Economics and Administration \\ Masarykova univerzita Masaryk University \\ $\triangle$ Lipová 41a, 60200 Brno, Czech Republic \\ E-mail: janeckova@econ.muni.cz
}

\section{Anotace}

Stat' se zabývá současným aktuálním tématem regionálni politiky a tím je čerpání prostředků z fondů EU. Cílem př́spěvku bylo zhodnotit naplñováni střednědobých cílu Moravskoslezského kraje v návaznosti na realizaci Regionálniho operačního programu NUTS II Moravskoslezsko 2007-2013. Moravskoslezský kraj prostřednictvím fondů EU má možnost čerpat nemalé prostředky pro svůj rozvoj a tím naplňovat principy a cíle regionálni politiky na svém území. Finančni zdroje z EU maji podporovat ekonomický růst, rozvoj podnikáni a životni úroven obyvatel Moravskoslezského kraje. Výstupy zkoumáni prokázaly opodstatněnost a pozitivni přinos strukturálnich fondủ při naplňování strednědobých cillu Moravskoslezského kraje. Včlánku je také poukázáno na problémy spojené s naplňováním jednotlivých cílů kraje.
\end{abstract}

\section{Klíčová slova:}

regionální politika, regionální rozvoj, NUTS, strukturální politika, strukturální fondy

\section{Annotation}

This essay discusses contemporary topics of a regional policy and elaborates on funds drawing from the EU. The aim of this article was to evaluate fulfilment of middle term aims of Moravian-Silesian region amongst the continuity of realization of Regional operational program NUTS II Moravskoslezsko 2007-2013. Moravian Silesian region has posibility to draw funds for its develpoment and thereby fulfill principles and aims of regional politics in its territory. Financial funds from the EU are to support economical growth, development of trading and living standards of citizens in Moravian Silesian region. The outcomes of examination has shown legitimacy and positive benefit of structural funds in the process of fulfilment of middle term aims of Moravian-Silesian region. In the article, there are also highlited problems connected with fulfilment of targets in particular regions.

\section{Key words:}

regional politics, regional development, NUTS, structural policy, structural funds

JEL classification: $R 58$ 


\section{Úvod}

Jedním z aktuálních témat současné doby je regionální politika, protože problematika regionálního rozvoje a zájem o regionální politiku z velké míry ovlivnil vstup České republiky (ČR) do Evropské unie (EU). Regionální politiku Evropské unie lze považovat za specifický fenomén, jenž nemá mimo EU obdoby. Je to jediná politika, jejíž hlavní poslání je snižování meziregionálních rozdílů v hospodářské úrovni regionů. Hlavním nástrojem strukturální a regionální politiky se staly strukturální fondy EU.

Základním účelem vytvořených strukturálních fondů je prostřednictvím rozvojových programů a projektů snižovat zaostalost znevýhodněných regionů včetně venkovských a zajistit v těchto oblastech vyrovnaný a udržitelný rozvoj. (Wokoun, Malinovský a kol., 2008).

Při porovnání vývoje hlavních faktorů regionálního rozvoje je patrná tendence prohlubování meziregionálních disparit. Výrazné prohloubení rozdílů $\mathrm{v}$ míře nezaměstnanosti na všech regionálních úrovních s kumulací ekonomických, ekologických i sociálních problémů se projevuje zejména v Moravskoslezském a Ústeckém kraji. Tyto kraje zasáhla nezbytná restrukturalizace prùmyslu spojená s vysokou nezaměstnaností, a je potřeba zde dostatečně rychle a efektivně realizovat nezbytné strukturální přeměny (Malinovský a kol., 2006, s. 238).

Celý Moravskoslezský kraj v byl rámci ČR zařazen mezi hospodářsky slabé a strukturálně postižené regiony. Také uvnitř samotného kraje existují oblasti, kde je dlouhodobě sledován horší socioekonomický vývoj než v ostatních částech kraje. Čerpání finančních prostředků z fondů EU v současném programovém období patří mezi priority kraje, z čehož vyplývá, že strukturální fondy hrají v regionální politice kraje významnou roli.

Moravskoslezský kraj patří k regionům, které se potýkají s nejzávažnějšími strukturálními problémy ovlivňující sociální a ekonomický život kraje. Moravskoslezský kraj je stále vnímán jako průmyslový region, protože jeho ekonomika byla založena na oborech hornictví, hutnictví a těžkého strojírenství. I když zde průmysl hraje stále klíčovou roli dochází ke změně odvětvové struktury, což s sebou také přináší sociální problémy a problémy související s restrukturalizací tohoto regionu.

Tematické zaměření regionální politiky Moravskoslezského kraje souvisí se sektorovým př́stupem $\mathrm{k}$ této problematice. Rozvojová témata definovaná v základním strategickém dokumentu Strategii rozvoje Moravskoslezského kraje 2009-2020 definují rozvojovou vizi kraje a pět globálních strategických cílů, které jsou dále rozpracovány do specifických strategických cílů.

Tab. 1: Vize a cíle Moravskoslezského kraje

\begin{tabular}{|l|l|}
\hline Rozvojová vize & $\begin{array}{l}\text { „Moravskoslezský kraj - konkurenceschopný region úspěšných a spokojených } \\
\text { lidí“ }\end{array}$ \\
\hline Globální cíl 1 & Konkurenceschopná, inovačně založená ekonomika \\
\hline Globální cíl 2 & Dobré vzdělání a vysoká zaměstnanost - př́ležitost pro všechny \\
\hline Globální cíl 3 & $\begin{array}{l}\text { Soudržná společnost - kvalitní zdravotnictví, cílené sociální služby a úspěšný } \\
\text { boj proti chudobě }\end{array}$ \\
\hline Globální cíl 4 & Kvalitní a kulturní prostředí, služby a infrastruktura pro život, práci a návštěvu \\
\hline Globální cíl 5 & Efektivní správa věcí veřejných \\
\hline
\end{tabular}

Zdroj: Strategie rozvoje Moravskoslezského kraje 2009-2020.

V současné době strukturální fondy hrají výraznou roli v regionální politice Moravskoslezského kraje, v období let 2007-2013 může kraj čerpat finanční prostředky na regionální rozvoj.

Operačním programem reflektujícím nejvýrazněji na potřeby regionální politiky kraje je Regionální operační program NUTS II Moravskoslezsko 2007-2013 (ROP MS), který je vytvořen pro období let 
2007-2013, ve kterém tento region patři do Cíle Konvergence. Byl zpracován v souladu s Obecnými strategickými zásadami Společenství a Národním strategickým referenčním rámcem. ROP MS byl schválen Evropskou komisí dne 3. 12. 2007 a poslední, 3. verze ROP MS byla schválena dne 20. 12. 2011 Evropskou komisí na základě rozhodnutí č.C(2011)9870. Tato verze zahrnuje navýšení prostředků na projekty regionální dopravní infrastruktury a na projekty investující do zvýšení kvality vzdělávání.

\section{Metodika}

Předmětem zkoumání bylo, zda jsou naplňovány střednědobé strategické cíle kraje pomocí projektů přijatých $\mathrm{k}$ financování $\mathrm{v}$ rámci Regionálního operačního programu NUTS II Moravskoslezsko 20072013. Zkoumaným obdobím bylo druhé programové období, tj. období 2007-2013. Podklady pro analýzu strategických projektů byly čerpány z databáze projektů Řídícího orgánu ROP MS k datu 31. 12. 2012. Hodnoceným programem byl střednědobý strategický dokument Program rozvoje Moravskoslezského kraje na období 2010-2012 (PRK), který podrobně rozpracovává úkoly vyplývající ze Strategie rozvoje Moravskoslezského kraje na léta 2009-2020 (Strategie MSK). Hodnotit míru naplnění cílů bylo značně problematické už z toho důvodu, že složitost problému spočívá ve způsobu formulování cílů. Jejich prílišná obecnost tak neumožňovala jednoznačné závěry. Hodnocení bylo z tohoto důvodu zaměřeno na to, zda jsou naplňovány krajské strategické projekty, které mají přinést nejvyšší možný užitek za podmínky účelně a hospodárně vynaložených finančních prostředků.

\section{Naplňování střrednědobých strategických cílů Moravskoslezského kraje}

Strategie rozvoje Moravskoslezského kraje na léta 2009-2020 definuje rozvojovou vizi kraje a pět globálních strategických cílů (tabulka č.1), dále rozpracovaných do 31 specifických cílů. Program rozvoje Moravskoslezského kraje na období 2010-2012 v hlavní strategické úrovni respektuje strukturu Strategie MSK, přičemž z původních 31 specifických cílů jich je v PRK rozpracováno 19, ve kterých byly definovány konkrétní projekty, jimiž bude PRK ve svém návrhovém období realizován.

Prostřednictvím realizace Regionálního operačního programu NUTS II Moravskoslezsko 2007-2013 jsou naplňovány následující globální a specifické cíle:

\section{Globální cíl 3 - Vzdělaná společnost aktivních a sebevědomých obyvatel}

\section{Specifický strategický cíl 3.4 Zvýšit počet a zlepšit připravenost osob zapojených do studia profesí strategických odvětví kraje dobře uplatnitelných na trhu práce}

\section{Výchozí situace:}

Moravskoslezský kraj se vyznačuje specifickými požadavky trhu práce vycházejícími z rozvoje tradiční ekonomiky kraje (odvětví uhelné, ocelářské, strojírenské, chemické, dřevozpracující a stavebních hmot) s novými strategickými ekonomickými prioritami (informační technologie, bezpečnost, mechatronika, nové materiály, obnovitelné zdroje, environmentální technologie). Cílem je vytvářet optimální podmínky pro výuku a dostatečný počet studentů odpovídající poptávce zaměstnavatelů, podpořit motivaci žáků $\mathrm{k}$ setrvání $\mathrm{v}$ oboru prostřednictvím kontaktu s novými technologiemi a firemním prostředím již během studia.

\section{Naplňování pomocí ROP MS:}

Tento specifický strategický cíl je naplňován prostřednictvím prioritní osy 2 Podpora prosperity regionu, oblasti podpory 2.1 Infrastruktura veřejných služeb, dílčí oblasti 2.1.1 Rozvoj infrastruktury pro vzdělávání. Oblasti podpory se zaměřje na hmotné investice v oblasti infrastruktury vzdělávání, kde jsou podporovány také projekty př́ípravy pracovníků pro strategická odvětví ekonomiky kraje. Podpora je poskytována na vybavení a provozování oborových center praktické přípravy pro klíčové obory kraje. Tento cíl je poměrně dobře a bezproblémově pomocí ROP MS naplňován. 
Tab. 2: Strategické projekty kraje - specifický strategický cíl 3.4

\begin{tabular}{|c|c|c|c|}
\hline Název projektu & Stav projektu & $\begin{array}{l}\text { Celkové } \quad \text { výdaje } \\
\text { projektu } \\
(\text { mil. Kč) }\end{array}$ & $\begin{array}{l}\text { Příspěvek } \\
\text { Společenství } \\
\text { (mil. Kč) }\end{array}$ \\
\hline Elektrotechnická centra & Projekt v realizaci & 41,36 & 35,07 \\
\hline Modernizace škol ve stavebnictví & Projekt v realizaci & 49,83 & 42,29 \\
\hline $\begin{array}{llll}\text { Vybavení } & \text { oborových } & \text { center } & - \\
\text { dřevoobráběcí } & \text { CNC stroje } & & \end{array}$ & Projekt ukončen & 30,13 & 25,61 \\
\hline Multifunkční posluchárny & Projekt ukončen & 16,54 & 11,57 \\
\hline $\begin{array}{l}\text { Centra technického vzdělávání na } \\
\text { Bruntálsku }\end{array}$ & Projekt ukončen & 58,27 & 46,89 \\
\hline Mechatronika & Projekt v realizaci & 37,79 & 45,15 \\
\hline 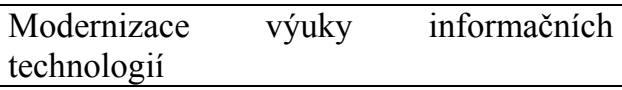 & Projekt schválen & 19,37 & 16,13 \\
\hline $\begin{array}{l}\text { Multifunkční a velkoprostorové odborné } \\
\text { učebny - gastrocentra }\end{array}$ & Projekt v realizaci & 11,10 & 9,18 \\
\hline Projekty celkem & & 264,39 & 231,89 \\
\hline
\end{tabular}

Zdroj: Program rozvoje Moravskoslezského kraje na obdobi 2010-2012, Databáze Řídicího orgánu ROP MS dni

31. 12. 2012, vlastni zpracování.

\section{Globální cíl 4 - Kvalitní a kulturní prostředí, služby a infrastruktura pro život, práci a návštěvu}

Specifický strategický cíl 4.1 Stát se krajem „služeb pro 5 milionů “ - rozšǐrít nabídku volnočasové infrastruktury a služeb pro obyvatele kraje a návštěvniky

Výchozí situace:

Nezbytnou podmínkou pro zvýšení atraktivity kraje jak pro místní obyvatele, tak pro obyvatele sousedních zemí a regionů je modernizace a výstavba volnočasové infrastruktury a infrastruktury služeb v kraji.

Naplňování pomocí ROP MS:

Specifický strategický cíl 4.1 je naplňován prioritními osami 2 Podpora prosperity regionu, oblast podpory 2.1 Infrastruktura veřejných služeb, dílčí oblastí 2.2.1 Výstavba, revitalizace a modernizace turistické infrastruktury, doprovodných služeb a atraktivit cestovního ruchu. Dále je to prostřednictvím prioritní osy 3 Rozvoj měst a prioritní osy 4 Rozvoj venkova. V rámci všech uvedených prioritních os je podporována infrastruktura pro volnočasové aktivity a rozvoj služeb.

Tab. 3: Strategické projekty kraje - specifický strategický cíl 4.1

\begin{tabular}{|c|c|c|c|}
\hline Název projektu & Stav projektu & $\begin{array}{l}\text { Celkové výdaje } \\
\text { projektu } \\
\text { (mil. Kč) }\end{array}$ & $\begin{array}{l}\text { Příspěvek } \\
\text { Společenství } \\
\text { (mil. Kě) }\end{array}$ \\
\hline $\begin{array}{l}\text { Novostavba Moravskoslezské vědecké } \\
\text { knihovny }\end{array}$ & $\begin{array}{l}\text { Realizace projektu nebyla } \\
\text { schválena zastupitelstvem } \\
\text { kraje }\end{array}$ & $x+3 x_{1}$ & $x_{1}$ \\
\hline $\begin{array}{l}\text { Př́stavba Domu umění - Galerie } 21 . \\
\text { století }\end{array}$ & V přípravě & $\mathrm{x}$ & $\mathrm{x}$ \\
\hline $\begin{array}{l}\text { Modernizace, rekonstrukce a výstavba } \\
\text { sportovišt' vzdělávacích zařízení I., II., } \\
\text { III., IV., VI., VII. }\end{array}$ & Projekt v realizaci & 178,15 & 216,14 \\
\hline $\begin{array}{l}\text { Revitalizace zámku ve Frýdku včetně } \\
\text { obnovy expozice }\end{array}$ & $\mathrm{V}$ přípravě & $\mathrm{x}$ & $\mathrm{x}$ \\
\hline Revitalizace hradu Hukvaldy & Ve fázi záměru & $\mathrm{x}$ & $\mathrm{x}$ \\
\hline Projekty celkem & & 178,15 & 216,14 \\
\hline
\end{tabular}


Naplňování strategického cíle 4.1 prostřednictvím projektů kraje je bezproblémové pouze v oblasti modernizace a výstavby sportovišst u vzdělávacích zařízení. Zde je realizováno 5 projektů v celkovém objemu výdajů cca 178,15 mil. Kč. Všechny projekty jsou v současné době v realizaci. Novostavba Moravskoslezské vědecké knihovny nebude prostřednictvím ROP MS realizována. Pro projekty př́stavby Domu umění a revitalizace zámku ve Frýdku je v současné fázi vyhlášeno výběrové rúzení na zpracovatele projektové dokumentace, jejich předložení do ROP MS se předpokládá. Projekt Revitalizace hradu Hukvaldy zatím není ani ve fázi př́ípravy.

\section{Specifický strategický cíl 4.4 Zajistit obyvatelưm kraje kvalitní zdravotní a sociální služby}

Výchozí situace:

Technický stav zařízení poskytujících sociální služby je v mnohých př́padech velmi špatný. V Moravskoslezském kraji nejsou sociální služby poskytovány rovnoměrně. S ohledem na vyšší efektivitu a kvalitu poskytování sociálních služeb je nutno zavádět ve větši míře terénní služby, služby sociální prevence a transformovat pobytová zařízení dle zákonných standardů.

V oblasti zdravotnictví je nutno zkvalitnit poskytovanou zdravotní péči. Je nezbytné realizovat taková opatření, která zajistí zkvalitnění péče a provozu zdravotnických zařízení prostřednictvím moderních technologí́.

Naplňování pomocí ROP MS:

Specifický strategický cíl 4.4 je naplňován prioritní osou 2 Podpora prosperity regionu, oblastí podpory 2.1 Infrastruktura veřejných služeb, dílčí oblastí 2.1.2 Rozvoj infrastruktury sociálních služeb a dílčí oblastí 2.1.3 Podpora zajištění efektivnosti a dostupnosti poskytování zdravotnických služeb.

Tab. 4: Strategické projekty kraje - specifický strategický cíl 4.4

\begin{tabular}{|c|c|c|c|}
\hline Název projektu & Stav projektu & 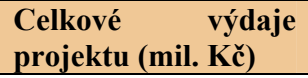 & $\begin{array}{l}\begin{array}{l}\text { Příspěvek Společenství } \\
\text { (mil. Kč) }\end{array} \\
\end{array}$ \\
\hline $\begin{array}{l}\text { Rekonstrukce objektu } \\
\text { chráněné bydlení }\end{array}$ & Projekt v realizaci & 12,17 & 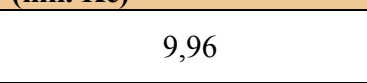 \\
\hline $\begin{array}{l}\text { Rekonstrukce objektu na chráněné bydlení } \\
\text { Sedlnice }\end{array}$ & Projekt v realizaci & 14,85 & 12,18 \\
\hline $\begin{array}{l}\text { Rekonstrukce objektu na domov pro osoby se } \\
\text { zdravotním postižením, Sírius Opava }\end{array}$ & Projekt v realizaci & 35,13 & 28,06 \\
\hline $\begin{array}{l}\text { Rekonstrukce objektu v Karviné na chráněné } \\
\text { bydlení, Polská ul.č.p.71 }\end{array}$ & Projekt ukončen & 10,07 & 8,06 \\
\hline $\begin{array}{l}\text { Rekonstrukce objektu v Novém Jičíně na } \\
\text { chráněné bydlení, Slovanská ul.č.p. } 1555\end{array}$ & Projekt ukončen & 8,27 & 6,79 \\
\hline $\begin{array}{l}\text { Chráněné bydlení a sociálně terapeutické dílny } \\
\text { ve Městě Albrechticích }\end{array}$ & Projekt v realizaci & 26,68 & 20,40 \\
\hline $\begin{array}{lll}\text { Rekonstrukce objektu v Budišově } & \text { nad } \\
\text { Budišovkou na chráněné bydlení } & \\
\end{array}$ & Projekt ukončen & 20,46 & 16,54 \\
\hline $\begin{array}{l}\text { Rekonstrukce objektu v Moravici na chráněné } \\
\text { bydlení }\end{array}$ & Projekt v realizaci & 14,26 & 12,06 \\
\hline $\begin{array}{l}\text { Rekonstrukce objektu Domova Jistoty, p.o. na } \\
\text { ulici Koperníkova v Novém Bohumíně }\end{array}$ & Projekt ukončen & 20,94 & 17,43 \\
\hline $\begin{array}{l}\text { Výstavba objektu chráněného bydlení na ulici } \\
\text { Koperníkova v Novém Bohumíně }\end{array}$ & Projekt ukončen & 9,72 & 7,96 \\
\hline $\begin{array}{l}\text { Obnova přístrojové techniky ve zdravotnických } \\
\text { zařízeních }\end{array}$ & Projekt v realizaci & 193,38 & 168,57 \\
\hline Vozidla pro život & Projekt ukončen & 53,28 & 45,28 \\
\hline Bezbariérovost zdravotnických zařízení & $\mathrm{x}$ & $\mathrm{x}$ & $\mathrm{x}$ \\
\hline $\begin{array}{l}\text { Rekonstrukce infekčního } \quad \text { pavilonu } \\
\text { v Nemocnici s poliklinikou Havířov, p.o. }\end{array}$ & Projekt v realizaci & 110,65 & 92,53 \\
\hline $\begin{array}{l}\text { Pavilon chirurgických oboru v Nemocnici ve } \\
\text { Frýdku-Místku, p.o. }\end{array}$ & Projekt v realizaci & 526,07 & 439,23 \\
\hline Data pro život & Projekt ukončen & 11,00 & 9,35 \\
\hline Projekty celkem & & 1066,93 & 894,4 \\
\hline
\end{tabular}

Zdroj: Program rozvoje Moravskoslezského kraje na obdobi 2010-2012, Databáze Řídicího orgánu ROP MS dni 
Všechny plánované strategické projekty voblasti sociálních služeb jsou již naplněny nebo se v současné době realizují. V rámci zdravotnických služeb jsou podporována krajská zdravotnická zařízení. Jediný projekt řešící bezbariérovost zdravotnických zařízení není dle plánu Programu rozvoje realizován.

\section{Specifický strategický cíl 4.5 Mít kvalitní vnitřní i vnější dopravní propojení kraje}

\section{Výchozí situace:}

Cílem v této oblasti je dokončení propojení silniční sítě nadregionálního významu, zkvalitnění krajské sítě silnic, rekonstrukce mostních objektů na krajských komunikacích. Zároveň jsou podporovány projekty zvyšování pasivní bezpečnosti na pozemních komunikacích. Vzhledem k tomu, že silniční doprava se podílí významným způsobem na zhoršování stavu životního prostředí v kraji, je nutné zvýšit podíl osob přepravovaných hromadnou dopravou nad dopravou individuální.

V oblasti železniční přepravy je nutno kromě modernizace a elektrifikace stávajících tratí realizovat takové projekty, které přispějí k lepší využitelnosti a dostupnosti železniční dopravy. K tomuto cíli má přispět projekt kolejového napojení Letiště Leoše Janáčka Ostrava. Letiště Leoše Janáčka Ostrava je významným strategickým bodem kraje a jeho rozvoj je prioritou kraje. Letiště má dobré technické parametry přistávací dráhy, ale není vybaveno pro provoz za nízké dohlednosti, nemá vybudováno vyhovující dopravní napojení a má také nedostatečné vybavení a zastaralou infrastrukturu.

Naplňování pomocí ROP MS:

Specifický strategický cíl 4.5 je naplňován pomocí prioritní osy 1 Regionální infrastruktura a dostupnost pomocí všech čtyř oblastí podpory.

Tab. 5: Strategické projekty kraje - specifický strategický cíl 4.5

\begin{tabular}{|c|c|c|c|}
\hline Název projektu & Stav projektu & $\begin{array}{l}\text { Celkové } \quad \text { výdaje } \\
\text { projektu } \\
\text { (mil. Kč) }\end{array}$ & $\begin{array}{l}\text { Příspěvek } \\
\text { Společenství (mil. } \\
\text { Kč) }\end{array}$ \\
\hline Mosty 2010 & Projekt ukončen & 167,08 & 100,99 \\
\hline Silnice 2008 - 3.část & Projekt ukončen & 419,63 & 329,18 \\
\hline SILNICE 2010 & Projekt v realizaci & 175,39 & 94,96 \\
\hline SILNICE 2011 & Projekt v realizaci & 522,27 & 352,82 \\
\hline $\begin{array}{l}\text { II/449 - Rýmařov - Ondřejov, rekonstrukce } \\
\text { silnice km } 0,00 \text { - 11,40, II. stavba }\end{array}$ & Projekt schválen & 214,54 & 114,90 \\
\hline Přeložka komunikace III/4682 - Vendryně & Projekt ukončen & 84,44 & 50,73 \\
\hline $\begin{array}{l}\text { Revitalizace přednádražního prostoru } \\
\text { Svinov, II. etapa - část MSK }\end{array}$ & Projekt v realizaci & 180,37 & 108,96 \\
\hline $\begin{array}{l}\text { Komunikace II/479 - ulice Českobratrská, } \\
\text { III. stavba }\end{array}$ & Projekt ukončen & 186,14 & 115,58 \\
\hline Silnice 2009 - obchvat Opava & Projekt v realizaci & 586,08 & 345,737 \\
\hline VIA Lyžbice & Projekt v realizaci & 164,57 & 105,62 \\
\hline Silnice 2009 & Projekt ukončen & 139,01 & 87,12 \\
\hline $\begin{array}{l}\text { Letiště Leoše Janáčka Ostrava, odbavovací } \\
\text { plocha }\end{array}$ & Projekt ukončen & 138,47 & 96,32 \\
\hline $\begin{array}{l}\text { Letiště Leoše Janáčka Ostrava, kolejové } \\
\text { napojení }\end{array}$ & $\begin{array}{l}\text { Bude presunut do } \\
\text { OP Doprava }\end{array}$ & $\mathrm{x}$ & $\mathrm{x}$ \\
\hline $\begin{array}{l}\text { Rekonstrukce a modernizace silnic II. a III. } \\
\text { tříd }\end{array}$ & Projekt ukončen & 243,00 & 206,25 \\
\hline Silnice III/4689 Petrovice & Projekt schválen & 81,78 & 51,15 \\
\hline $\begin{array}{l}\text { Rekonstrukce a modernizace silnic v MSK } \\
-7 \text { staveb }\end{array}$ & Projekt ukončen & 285,28 & 238,67 \\
\hline Projekty celkem & & 3588,05 & 2398,99 \\
\hline
\end{tabular}

Zdroj: Program rozvoje Moravskoslezského kraje na obdobi 2010-2012, Databáze Řídicího orgánu ROP MS dni 
Plánované strategické projekty kraje jsou již naplněny. Jediným nenaplněným projektem je projekt, který řeší kolejové napojení Letiště Leoše Janáčka Ostrava, a to z důvodu, že se plánuje jeho předložení do Operačního programu Doprava.

\section{Specifický strategický cíl 4.8 Zlepšit bezpečnost, ochranu zdraví a majetku obyvatel kraje}

Výchozí situace:

Území kraje je vystaveno různým rizikům (povětrnostní a klimatické podmínky, nárůst intenzity dopravy, riziko průmyslových havárií apod.). Rozvoj integrovaného záchranného systému a úzká koordinace záchranných složek přinese zkvalitnění a zrychlení pomoci občanům a výrazně sníží následky nepředvídaných událostí na zdraví, životy a majetek obyvatel.

Tab. 6: Strategické projekty kraje - specifický strategický cíl 4.8

\begin{tabular}{|l|l|l|l|}
\hline Název projektu & Stav projektu & $\begin{array}{l}\text { Celkové } \\
\text { projektu } \\
\text { (mil. Kč) }\end{array}$ & $\begin{array}{l}\text { Př́íspěvek Společenství } \\
\text { (mil. Kč) }\end{array}$ \\
\hline $\begin{array}{l}\text { Integrované bezpečnostní } \\
\text { centrum }\end{array}$ & Projekt ukončen & 696,68 & 577,25 \\
\hline
\end{tabular}

Zdroj: Program rozvoje Moravskoslezského kraje na období 2010-2012, Databáze Řídícího orgánu ROP MS dni 31. 12. 2012, vlastní zpracování.

\section{Globální cíl 5 - Efektivní správa věcí veřejných}

\section{Specifický strategický cíl 5.6 Zlepšit image kraje navenek i dovnitř}

Výchozí situace:

Moravskoslezský kraj již delší dobu usiluje o změnu image regionu. Mediální obraz kraje je negativní a je horší než u jiných krajů. Marketingové aktivity budou zaměřeny na turisty ze všech perspektivních destinací, investory, ale také obyvatele kraje a podnikatele v kraji. Cílem je, aby kraj byl vnímán jako místo atraktivní pro život obyvatel, práci i návštěvu.

Naplňování pomocí ROP MS:

Specifický strategický cíl 5.5 je naplňován pomocí prioritní osy 2 Podpora prosperity regionu, oblasti podpory 2.4 Marketing regionu a 2.2 Rozvoj cestovního ruchu.

Tab. 7: Strategické projekty kraje - specifický strategický cíl 5.6

\begin{tabular}{|l|l|c|c|}
\hline Název projektu & Stav projektu & $\begin{array}{l}\text { Celkové } \\
\text { projektu } \\
\text { (mil. Kč) }\end{array}$ & $\begin{array}{l}\text { výdajéspěvek } \\
\text { Společenství } \\
\text { (mil. Kč) }\end{array}$ \\
\hline Kraj mnoha barev a př́ležitostí II & Projekt ukončen & 30,10 & 25,58 \\
\hline $\begin{array}{l}\text { Využití marketingové strategie } \\
\text { vaktivitách cestovního ruchu v MSK II }\end{array}$ & Projekt ukončen & 60,10 & 51,08 \\
\hline $\begin{array}{l}\text { Moravskoslezský kraj - kraj plný } \\
\text { zážitků }\end{array}$ & Projekt ukončen & 40,46 & 34,39 \\
\hline $\begin{array}{l}\text { Moravskoslezský kraj - kraj plný } \\
\text { zážitků -2 }\end{array}$ & Projekt v realizaci & 32,40 & 27,54 \\
\hline $\begin{array}{l}\text { Industriální } \\
\text { v Moravskoslezském kraji }\end{array} \quad$ aktivity & Projekt v realizaci & 14,57 & 12,38 \\
\hline Jesenická magistrála & Projekt schválen & 19,85 & 15,47 \\
\hline Beskydská magistrála & Projekt ukončen & 8,08 & 6,65 \\
\hline Projekty celkem & & $\mathbf{2 0 5 , 5 6}$ & $\mathbf{1 7 3 , 0 9}$ \\
\hline
\end{tabular}

Zdroj: Program rozvoje Moravskoslezského kraje na období 2010-2012, Databáze Řidicího orgánu ROP MS dni 
Plánované strategické projekty kraje ve specifickém strategickém cíli 5.5 jsou všechny naplňovány. Čtyři ze sedmi projektů již byly zrealizovány, další jsou v realizaci.

\section{Závěr}

Regionální operační program NUTS II Moravskoslezsko 2007-2013 pomáhá naplňovat tři z pěti globálních cílů a šest specifických strategických cílů stanovených v Programu rozvoje Moravskoslezského kraje na období 2010-2012. V každém globálním cíli jsou Moravskoslezským krajem stanovené strategické projekty a úkolem kraje je tyto projekty naplnit. V Globálním cíli 3 jsou realizovány všechny strategické projekty v objemu celkových výdajů 264,4 mil. Kč. Investice jsou zde prostřednictvím ROP MS směřovány do oblasti infrastruktury vzdělávání. Cíl je poměrně dobře a bezproblémově pomocí ROP MS naplňován. V Globálním cíli 4 jsou prostřednictvím ROP MS naplňovány čtyři z osmi specifických cílů. V oblasti rozšíření nabídky volnočasové infrastruktury a služeb $\mathrm{v}$ kraji je bezproblémové naplňování pouze $\mathrm{v}$ oblasti výstavby sportovišt' u vzdělávacích zařízení. Problémovým projektem je projekt novostavby Moravskoslezské vědecké knihovny, který není a nebude $\mathrm{v}$ tomto plánovacím období realizován. Ostatní plánované projekty jsou bud' v př́ípravě, nebo jen ve fázi záměru. $\mathrm{V}$ oblasti zkvalitnění zdravotnických a sociálních služeb není realizován pouze jeden strategický projekt. Zkvalitnění dopravního propojení kraje je úspěšně naplňováno kromě jediného projektu, kterým je kolejové napojení Letiště Leoše Janáčka v Ostravě. V současné době se připravuje podání tohoto projektu do OP Doprava. Oblast zlepšení bezpečnosti, ochrany zdraví a majetku obyvatel je již díky výstavbě Integrovaného bezpečnostního centra v Moravskoslezském kraji s celkových výdajích 697 mil. Kč naplněna. V globálním cíli 5 je zlepšován image kraje. Strategické projekty stanovené krajem jsou zde také bezproblémově naplňovány.

Pomocí analýzy bylo prozkoumáno naplňování střednědobých cílů Moravskoslezského kraje stanovených ve strategickém dokumentu Program rozvoje Moravskoslezského kraje na období 20102012 prostřednictvím Regionálního operačního programu NUTS II Moravskoslezsko 2007-2013. Analýza prokázala opodstatněnost a pozitivní př́nos strukturálních fondů při naplňování střednědobých cílů Moravskoslezského kraje.

\section{Literatura}

[1] MALINOVSKÝ, J. a kol. Metody regionálního rozvoje pro potřeby strategického rozvoje regionů. Program Výzkumu a vývoje Ministerstva pro mistní rozvoj $\check{C} R$ : Projekt: WA-003-05Z12. Ostrava: Vysoká škola báňská - Technická univerzita Ostrava, 2006. 320 s.

[2] Program rozvoje Moravskoslezského kraje na obdobi 2010-2012.

[3] Regionálni operačni program NUTS II Moravskoslezsko 2007-2013.

[4] Strategie rozvoje Moravskoslezského kraje 2009-2020.

[5] WOKOUN, R., MALINOVSKÝ J. a kol. Regionální rozvoj. LINDE PRAHA, A.S., 2008. ISBN 978-80-7201-699-0. 